\title{
PREPARATION AND EVALUATION OF MUPIROCIN LOADED POLYMER COMPOSITE FILMS
}

\author{
"Saleem. MA, Naheed MD, Murali YD, Patel Jaydeep, Malvania Dhaval
}

Luqman College of Pharmacy, Gulbarga, Karnataka, INDIA-585 102

"Corresponding author's E-mail: ssaleempharm@gmail.com, Mobile: 09036663835

Received 29 March 2012; Revised 25 April 2012; Accepted 07 May 2012, Available online 15 May 2012

\begin{abstract}
ABS TRACT
Polymer composite films were prepared by using chitosan and sodium alginate alone and in combination with aloe vera, with \& without glutaraldehyde were prepared by solvent casting method. Mupirocin was incorporated into selected polymeric films. All the poly meric composite films were characterized by IR study suggested that there was no chemical reaction has taken place, only ionic complex was formed. All the films were evaluated for thickness, folding endurance, and tensile stren gth. The thickness of all the films was uniform as the concentration of polymer was kept constant. The folding endurance suggested good flexibility of the films as propylene glycol was used as a plasticizer. The water vapour penetration suggested that films prepared without cross linker absorbs more moisture as compared to films containing cross linking agent. All the films subjected to tensile strength and in-vitro bio adhesion. The films showed good tensile strength, suggested good mechanical property for handling of dressing film. All the films showed the good bioadhesion, which must require to adhere perfectly over the wound. The presence of cross linking agent decreases the bioadhesion. All the polymer composite films were evaluated for in vitro swelling study. The films showed good swelling in water more than 6 hrs retaining the shape of the films. The addition of cross linking agent decreased the swelling. Selected polymer composite films were evaluated for in vivo wound healing activity. All the polymeric films showed more than $80 \%$ reduction in wound contraction. The mupirocin loaded polymeric composite containing aloe vera, shown more than $98 \%$ of reduction in wound area after $12^{\text {th }}$ day. Hence, from the overall study it can be concluded that poly mer composite films of chitosanalginate containing mupirocin along with aloe vera showed good wound healing and could be used in effective management of all type of wounds.
\end{abstract}

Keywords: Chitosan; sodium algin ate; aloe vera; mupirocin; poly mer composite films; wound healing.

\section{INTRODUCTION}

According to the Wound Healing Society, a wound is the result of disruption of normal anatomic structure and function. Based on the nature of repair process, wound can be classified as acute or chronic wounds ${ }^{1}$. The management of wounds can be done by using different wound dressings which have been developed over the years from the crude applications of plant herbs, animal fat and honey to tissue engineered scaffolds ${ }^{2}$. Recognition of the importance of clean liness and good aseptic practice in medicine and surgery has lead to improvements in the management of quality of wound management materials ${ }^{3}$. In the last few decades lot of work have been done towards effective management of wound. In the present scenario of advanced technology, modern wound dressing have been introduced which include hydrocolloid dressing, alginate/chitosan dressing and hydrogel dressing not only as bandage but also in the form of sponges, fiber, films and solution ${ }^{4}$. Chitosan is currently receiving a great deal of attention for medical and pharmaceutical applications due to its beneficial intrinsic properties. Chitosan is a deacetylated chitin derivative containing amino sugar. Chitosan possess many properties that are advantageous for wound dressing, namely bio-compatibility, biodegradability, haemostatic activity, anti-infection and wound acceleration properties ${ }^{5}$. Alginate is another polymer which is bio-degradable and obtained from natural orig in having wound healing property and good bio-adhesion which is necessary for more retention over the skin ${ }^{6}$. Prajapati et al worked on polyelectrolyte complex of chitosan alginate for local drug delivery and explain that combination of appropriate drug and chitosan can help to recover topical infections. Polyelectrolyte complex film of chitosan and sodium alginate film can be used for sustained drug delivery of potent antimicrobial and antifungal drugs by transdermal drug delivery ${ }^{7}$. Aloe vera also known as true or medical aloe is species of succulent plant, which is used as herbal medicine. Aloe vera is used topically and systemically for the treatment of different diseases. Aloe vera could improve wound healing after topical application by the different mechanisms, such as keeping the wound moist, increase epithelial cell migration and more rapid maturation of collagen and reduction in inflammation. Aloe vera has skin hydration effects, anti-microbial and anti-fungal activity ${ }^{8}$. The purpose of applying antibiotics and other antibacterial is mainly to prevent or combat infections especially for diabetic foot ulcers, surgical and accidents wound where the incident of infections can be high due to reduced resistance resulting from extreme trau ma ${ }^{9}$. Mupirocin is a topical antimicrobial indicated in the treatment of impetigo and secondary skin infections. Mupirocin is an antibiotic produced from pseudomonas fluorescens and structurally unrelated to any other topical or systemic antibiotic. Commercially it is available in the form of creams and ointments for topical application ${ }^{10}$.

Hence in the present work an attempt will be made to prepare and evaluate polymeric composite films of chitosan-alginate and incorporated with mupirocin and aloe vera extracts for the effective management of different types of wounds.

\section{MATERIALS AND METHOD}

Chitosan was obtained as gift sample from India Sea Foods, Cochin, Kerala and mupirocin was obtained as gift sample from Glen mark Pharmaceuticals Ltd, Nasik, Pune. 
Saleem et al

Aloe vera was obtained from the Bio-max Life Sciences, Hyderabad.

\section{Preparation of polymer composite films}

The films were prepared by solvent casting method ${ }^{11}$ as shown in Table 1. Polymeric films of chitosan alone and along with aloe vera was prepared by dispersing specified amount of chitosan dispersed in $3 \% \mathrm{v} / \mathrm{v}$ lactic acid in water, agitated for $1 \mathrm{~h}$ and add aloe vera into the chitosan dispersion followed by addition of glutaraldehyde with gentle stirring, then add the propylene glycol. The mixed solution was left to stand until air bubbles had disappeared, then poured onto a petri dish and allowed to air-dry at $40^{\circ} \mathrm{C}$ for $24 \mathrm{~h}$. To prepare chitosan-alginate composite
Journal of Drug Delivery \& Therapeutics; 2012, 2(3): 167-172 films, sodium alg inate solution was prepared by dissolving the alginate alone and along with aloe vera in the deionised water followed by chitosan solution which was prepared by dispersion of the chitosan in to $3 \% \mathrm{v} / \mathrm{v}$ lactic acid. Acetone was added to alginate solution. Finally the dispersed solution of the chitosan was added to sodium alginate solution drop wise under rapid agitation, then glutaraldehyde $(0.03 \% \mathrm{v} / \mathrm{v})$ was added followed by propylene glycol. The casting and drying of the films was done similar as explained above. ${ }^{8}$ Similarly mupirocin incorporated films were prepare by adding mupirocin in alginate solution and followed the same procedure as explained above.

Table 1: Formulation of polymer composite films

\begin{tabular}{|l|c|c|c|c|c|c|c|c|c|c|c|c|}
\hline Ingre dients (\% w/v) & F1 & F2 & F3 & F4 & F5 & F6 & F7 & F8 & F9 & F10 & F11 & F12 \\
\hline Chitosan & 3 & 3 & 2 & 2 & 1.5 & 1.5 & 1 & 1 & 1.5 & 1.5 & 1 & 1 \\
\hline Sodium alg inate & -- & -- & -- & -- & 1.5 & 1.5 & 1 & 1 & 1.5 & 1.5 & 1 & 1 \\
\hline Aloe vera & -- & -- & 1 & 1 & -- & -- & 1 & 1 & -- & -- & 1 & 1 \\
\hline Mupirocin & -- & -- & -- & -- & -- & -- & -- & -- & 2 & 2 & 2 & 2 \\
\hline Glutaraldehyde & -- & 0.03 & -- & 0.03 & -- & 0.03 & -- & 0.03 & -- & 0.03 & -- & 0.03 \\
\hline Propylene Glycol & 0.5 & 0.5 & 0.5 & 0.5 & 0.5 & 0.5 & 0.5 & 0.5 & 0.5 & 0.5 & 0.5 & 0.5 \\
\hline
\end{tabular}

\section{Characterization of polymer composite films}

\subsection{Foureir-transfor mation infrared s pectroscopy (FTIR)}

The drug-polymer and poly mer-poly mer interaction were studied using FTIR spectrometer (Perkin-Elmer (spectrum100) Japan) by taking $2 \% \mathrm{w} / \mathrm{w}$ of the sample with respect to potassium bromide disc, ground in to a fine powder and then compressed into a discs in a hydraulic press. Each disc was scanned 16 times at $2 \mathrm{~mm} / \mathrm{sec}$ at a resolution of 4 $\mathrm{cm}^{-1}$ using adopization. The characteristics peaks were recorded.

\section{Evaluation of polymer composite films}

\subsection{Thickness ${ }^{7}$}

The thickness of film influence the time required to absorb the polymer into the body. To determine the uniformity in thickness of film and change in thickness film after drug loading, it was measured for each film using screw gauge at three different sites of the film and the mean was calculated.

\subsection{Fol ding endur ance}

It was determined to find the flexibility of film which is needed to handle the film easily and for comfortable, secured application of film on the wound. It was determined by repeatedly folding one film at same place till it breaks or folded up to 300 times manually. The number of times of film could be folded at the same place without breaking give the value of folding endurance ${ }^{12}$.

\subsection{Swelling index}

Weighed pieces $\left(1 \mathrm{~cm}^{2}\right)$ of film were immersed in distilled water, then soaked films were removed from the medium at predetermined time, blotted to remove excess liquid and weighed immediately ${ }^{12}$. The swelling index was calculated

$$
\text { as } \% \mathbf{S}=\frac{w_{2}-w_{1}}{w_{1}} \times 100 \text {. }
$$

Where $\mathbf{w} \mathbf{1}$ and $\mathbf{w} \mathbf{2}$ are the weight of the film before and after immersion in the medium.

\subsection{Water vapour penetration}

To measure the water vapour penetration, the films were cut and placed on top of open 2.5- $\mathrm{cm}$ bottles containing $5 \mathrm{~g}$ of silica gel and held in place with a screw lid (test area: $4.9 \mathrm{~cm}^{2}$ ). The bottles were conditioned in desiccators containing silica gel for $12 \mathrm{~h}$. The bottles were then placed in desiccators containing a saturated solution of sodium chloride at $75 \% \mathrm{RH}$. The equilibrium vapour penetration was determined by weighing the bottles at $0,12,24$ and 48 hours respectively ${ }^{12}$.

\subsection{Tensile strength ${ }^{14}$}

The mechanical properties of films were evaluated using a texture analyzer (Instron Universal Model) equipped with a $500 \mathrm{gm} \mathrm{load} \mathrm{cell}^{13}$. Film strip in $10 \mathrm{~mm} \mathrm{X} 10 \mathrm{~mm}$ of dimension and free from air bubbles or physical imperfections, was held between two clamps positioned at a distance of $1 \mathrm{~cm}$. During measurement, the film was pulled by top clamp at a rate of $10 \mathrm{~mm} /$ minutes. The force and elongation were measured when the films broke. The tensile strength was calculated as,

Tensile strength $\left(\mathrm{kg} / \mathrm{mm}^{2}\right)=$ Breaking force $(\mathrm{kg}) /$ Cross sectional area of sample $\left(\mathrm{mm}^{2}\right)$

\subsection{Invitro bioadhesion study}

The bioadhesive property of the film was performed using an in-house pulley system instrument ${ }^{13}$. The proximal portion of a chicken pouch was used to represent the mucous-like texture of a fresh wound. The freshly slaughtered chicken pouch washed with physiological saline at $4{ }^{\circ} \mathrm{C}$ and attached to a platform (test area: 4.9 $\mathrm{cm}^{2}$ ). A prewetted film was placed a top the chicken pouch and held under $100 \mathrm{~g}$ weight for $2 \mathrm{~min}$, with the other side of the weight connected to a pulley system. The water was added to a container attached to the pulley system until the 
Saleem et al

film was detached. The weight of water needed to detach the film from the intestine was recorded.

\subsection{Wound healing acti vity by excision model}

Male Wister albino rats $(150-250 \mathrm{~g})$ in a total 8 groups of each having three animals were used after obtaining approval from institutional animal ethics committee (No.346/CPCSEA) by excision wound model $1^{13,14,15}$. Animals were housed under standard conditions of laboratory. Excision wound was inflicted under light ether anesthesia by excising a circular piece of $\left(20 \mathrm{~mm}^{2}\right)$ of full thickness skin from the dorsal interscapular region. Selected films were adhering over the wound and marketed povidone-iodine was used as a standard. Wound contraction was monitored by measuring wound area planimetrically, every alternate day till the wound was completely healed. Wound contraction was calculated as percent reduction in wound.

\section{RES ULTS AND DISCUSS UION}

In the present study natural based polymer composite films were prepared for the effective management of wound. To
Journal of Drug Delivery \& Therapeutics; 2012, 2(3): 167-172 enhance the therapeutic efficacy of the film antimicrobial agents like mupirocin and wound healing accelerators like aloe vera was incorporated in the film. Chitosan and sodium alginate was used as main polymers alone and along with aloe vera was followed by glutaraldehyde as cross linking agent and propylene glycol as a plasticizer. All the films were prepared by solvent casting method. The characterization of prepared poly mer composite films was studied by FTIR (Fourier's transform infrared spectroscopy) and the obtained spectra are represented in Figure 1. The IR study confirms that mupirocin remains intact in the polymer composite and also the IR spectrum of chitosan with sodium alginate results in formation of ionic complexes as both the polymers are polyionic. Chitosan contains cationic amino group which interact ionically with anionic carboxylic group of alginate and further glutaraldehyde crosslinked within chitosan to form strong ionic complex.

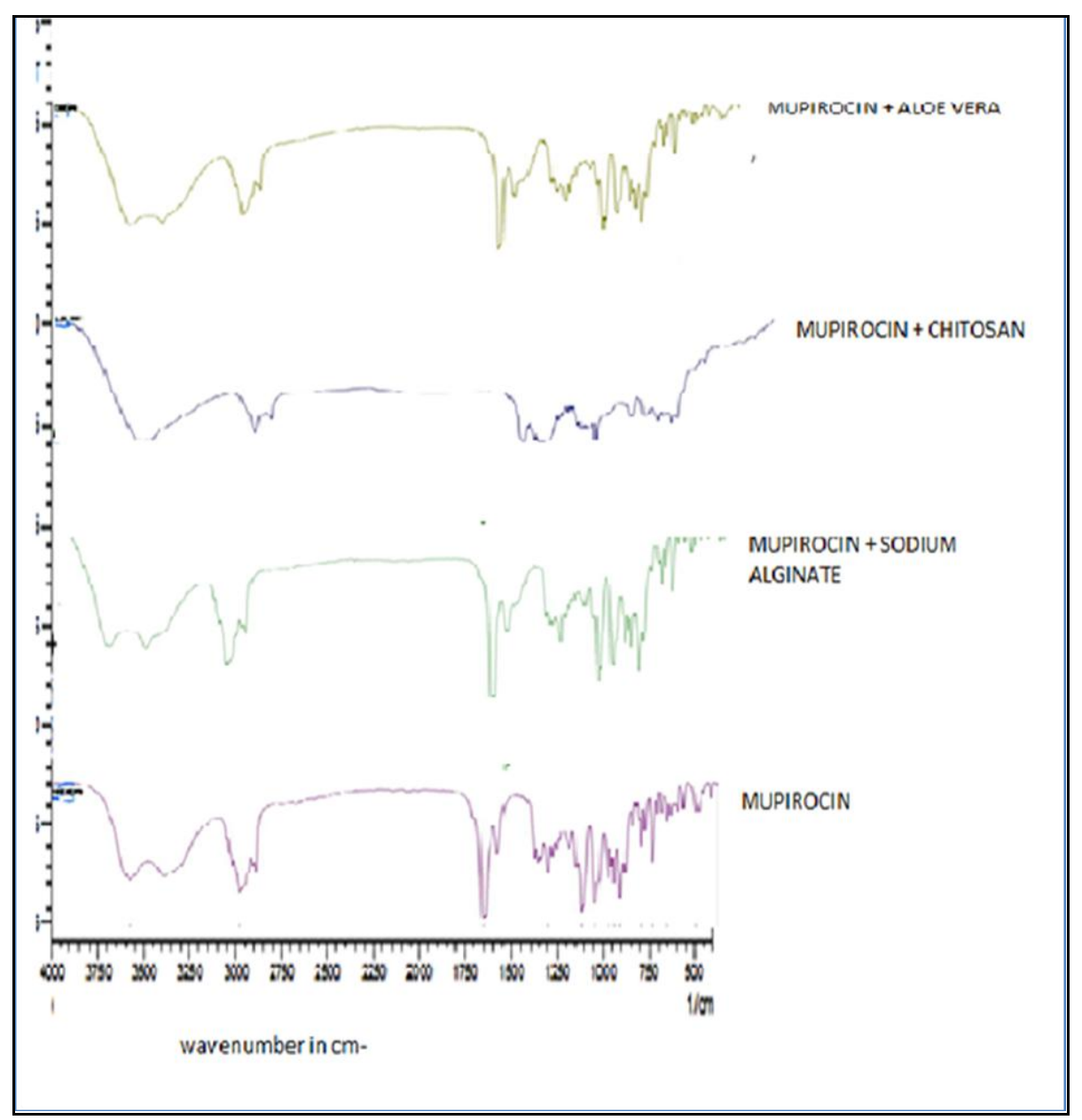

Figure 1: FTIR spectra of mupirocin loaded polymer composite films 


\section{Saleem et al}

All the polymer composite films were evaluated for different parameters and results are tabulated in Table 2. The thickness was varied from 0.6 to $1.0 \mathrm{~mm}$ as the total polymer concentration was kept constant (3\% w/w). Chitosanalginate composite films along with aloe vera without glutaraldehyde showed the thickness $0.6 \pm 0.0577 \mathrm{~mm}$. The thickness of the films was increased when the cross linker was added. The water vapour penetration of films had showed the percent increase in weight as shown in Table 2,
Journal of Drug Delivery \& Therapeutics; 2012, 2(3): 167-172

from $26.22 \pm 0.66 \%$ to $77.94 \pm 0.89 \%$. The water vapour permeability of the films was decrease with the increase in the concentration of the chitosan in the films. Thickness and the water vapour permeability inversely related, with thinnest films showed the highest water vapour permeability and vice-versa. The water vapour permeability of the mupirocin incorporated films showed from $28.44 \pm 0.68 \%$ to $65.23 \pm 0.99 \%$.

Table 2: Evaluation parameters of polymer composite films

\begin{tabular}{|c|c|c|c|c|c|c|}
\hline FC & $\begin{array}{c}\text { Thickness } \\
(\mathbf{m m})\end{array}$ & $\begin{array}{c}\text { Fol ding } \\
\text { endurance }\end{array}$ & $\begin{array}{c}\text { Water Vapor } \\
\text { penetration } \mathbf{( \% )}\end{array}$ & $\begin{array}{c}\text { Tensile strength } \\
\left(\mathbf{K g} / \mathbf{m m}^{\mathbf{2}}\right)\end{array}$ & $\begin{array}{c}\text { Maximum swelling } \\
\text { index } \mathbf{( \% )}\end{array}$ & $\begin{array}{c}\text { In-vitro bioadhesion } \\
\mathbf{g m} / \mathbf{c m}^{\mathbf{2}}\end{array}$ \\
\hline F1 & $0.8 \pm 0.05$ & $235 \pm 5.21$ & $61.61 \pm 1.22$ & $0.122 \pm 0.01$ & $2542.85 \pm 12.22$ & $21.28 \pm 0.58$ \\
\hline F2 & $1 \pm 0.06$ & $258 \pm 2.86$ & $26.22 \pm 0.66$ & $0.296 \pm 0.02$ & $1114.28 \pm 8.22$ & $11.59 \pm 0.64$ \\
\hline F3 & $0.7 \pm 0.05$ & $177 \pm 2.52$ & $77.94 \pm 0.89$ & $0.128 \pm 0.01$ & $1811.11 \pm 9.05$ & $19.24 \pm 0.44$ \\
\hline F4 & $0.8 \pm 0.07$ & $210 \pm 2.05$ & $32.80 \pm 0.45$ & $0.266 \pm 0.01$ & $922.22 \pm 7.94$ & $12.47 \pm 0.33$ \\
\hline F5 & $0.7 \pm 0.07$ & $194 \pm 4.51$ & $77.66 \pm 0.42$ & $0.258 \pm 0.02$ & $2900 \pm 13.12$ & $26.98 \pm 0.39$ \\
\hline F6 & $0.9 \pm 0.05$ & $219 \pm 3.25$ & $57.33 \pm 0.88$ & $0.294 \pm 0.04$ & $1144.44 \pm 8.99$ & $25.95 \pm 0.54$ \\
\hline F7 & $0.6 \pm 0.05$ & $208 \pm 2.25$ & $68.42 \pm 0.58$ & $0.244 \pm 0.08$ & $2340 \pm 12.58$ & $26.12 \pm 0.45$ \\
\hline F8 & $0.9 \pm 0.06$ & $222 \pm 2.51$ & $48.44 \pm 0.64$ & $0.276 \pm 0.06$ & $1266.66 \pm 13.52$ & $24.25 \pm 0.77$ \\
\hline F9 & $0.8 \pm 0.05$ & $195 \pm 3.52$ & $65.23 \pm 0.99$ & $0.245 \pm 0.02$ & $911.70 \pm 7.42$ & $22.12 \pm 0.59$ \\
\hline F10 & $1 \pm 0.03$ & $214 \pm 8.14$ & $30.0 \pm 1.01$ & $0.296 \pm 0.02$ & $724.42 \pm 7.92$ & $21.41 \pm 0.12$ \\
\hline F11 & $0.7 \pm 0.05$ & $211 \pm 3.61$ & $47.35 \pm 0.68$ & $0.242 \pm 0.06$ & $965.29 \pm 7.35$ & $22.66 \pm 0.31$ \\
\hline F12 & $0.9 \pm 0.05$ & $210 \pm 5.21$ & $28.44 \pm 0.65$ & $0.278 \pm 0.05$ & $850 \pm 6.75$ & $20.25 \pm 0.78$ \\
\hline
\end{tabular}

$(\mathbf{F C}=$ Formulation Cod $\quad$ Note: Values in parenthesis are standard de viation $( \pm \mathrm{SD}) ; n=3)$

The tensile strength of polymer composite films expressed in $\mathrm{Kg} / \mathrm{mm}^{2}$ as depicted in Table 2. Tensile strength represents the mechanical property of the films for the safe handling of dressing. Tensile strength depends upon the polymer, presence of plasticizer and addition of glutaraldehyde. The tensile strength of polymer composite films was $0.122 \pm$ 0.0115 to $0.296 \pm 0.0130 \mathrm{Kg} / \mathrm{mm}^{2}$. The results suggested that films containing glutaraldehyde showed decrease in tensile strength due to more flexibility of films as compared to films did not contained glutaraldehyde. The addition of mupirocin in the chitosan-alginate composite films did not affect the tensile strength.

All the prepared poly mer composite films were evaluated for bioadhesion and results are depicted in Table 2. The

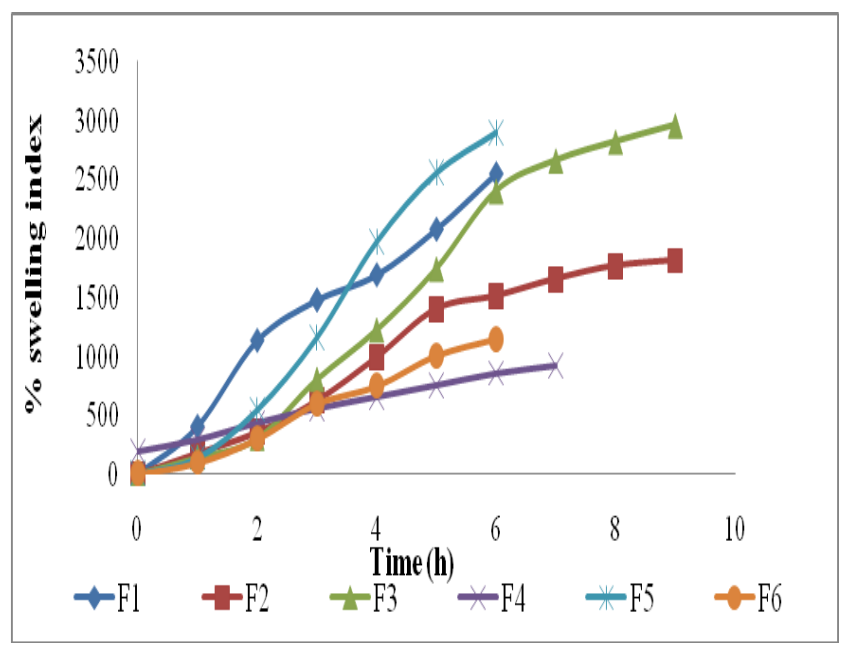

Figure 2: Swelling study of polymer composite films with and without glutaraldehyde along with aloe vera bioadhesion is an important property required to adhere to the wound for effective healing of the wound. The bioadhesion is affected by nature and molecular weight of polymer used, presence of cross linker, contact time and the degree of swelling of polymer. Chitosan and alginates are highly hydrophilic cationic and anionic polymers and hydrated to form slightly adhesive mucilage. The bioadhesion of polymer composite films was in the range of $11.59 \pm 0.69$ to $26.98 \pm 0.39$. The bioadhesion was decreased by the addition of glutaraldehyde. The addition of mupirocin in the chitosan-alginate composite films did not affect the bio-adhesion. All the prepared composite films were evaluated for swelling index, and average swelling index is depicted in Table 2 and also the data up to $9 \mathrm{~h}$ is $\begin{array}{llllll}\text { represented in } & \text { figure } & 2 & \& & 3 .\end{array}$

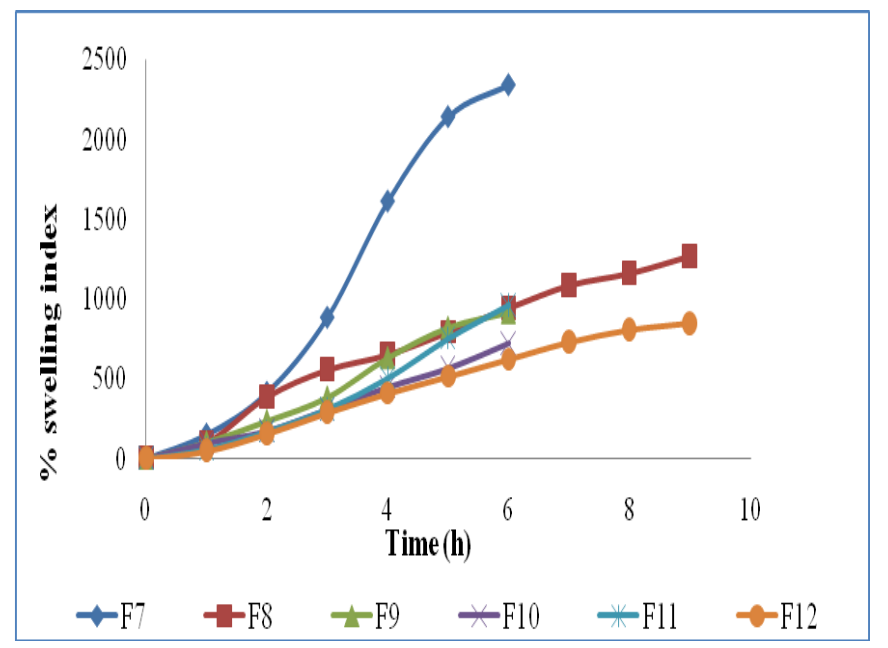

Figure 3: Swelling study of mupirocin incorporated polymer composite films with and without glutaraldehyde along with aloe vera 
Saleem et al

The swelling behavior is related with the mucoadhesion and depends on the nature and viscosity of polymer, media used and the presence of cross linker. The degree of swelling increased as the time passes and at certain time some of the formulations loose the integrity which did contained glutaraldehyde. In the chitosan composite films, chitosan alone showed rapid swelling up to $6 \mathrm{~h}$ and could not hold the shape, whereas addition of aloe vera prolonged the swelling up to $9 \mathrm{~h}$. The percent swelling of poly mer composite films was from $911.70 \pm 7.42$ to $2900 \pm 13.12$ (F1-F8). Mupirocin incorporated films showed the swelling from $724.42 \pm 7.92$ to $965.29 \pm 7.35$ (F9-F12). Addition of glutaraldehyde
Journal of Drug Delivery \& Therapeutics; 2012, 2(3): 167-172

decreased the swelling due to formation of more rigid network. Wound healing is a process by which damaged tissue is restored as closely as possible to its normal state. Wound contraction is the process of shrinkage of area of the wound. It mainly depends on the repairing ability of tissue, which may be reduced due to infection. Chitosan-alginate composite films containing aloe vera and mupirocin with and without glutaraldehyde were subjected to in vivo wound healing activity by method of excision model in albino rats. The results are expressed in percent contraction in wound area as depicted in Table $3 \& 4$ and also represented in bar graph in figure 4 and 5.

Table 3: Wound healing data of poly mer composite films formu lated with and without glutaraldehyde along with aloe vera

\begin{tabular}{|c|c|c|c|c|c|c|}
\hline \multirow{2}{*}{$\begin{array}{c}\text { Post- } \\
\text { wounding } \\
\text { days }\end{array}$} & \multicolumn{6}{|c|}{ Wound area $(\mathrm{mm})$} \\
\hline & Control & Standard & $\mathbf{F 5}$ & F6 & F7 & F8 \\
\hline 0 & $\begin{array}{c}20.03 \pm 0.81 \\
(0 \%)\end{array}$ & $\begin{array}{c}20.35 \pm 0.76 \\
(0 \%)\end{array}$ & $\begin{array}{c}20.06 \pm 0.42 \\
(0 \%)\end{array}$ & $\begin{array}{c}19.92 \pm 0.93 \\
(0 \%)\end{array}$ & $\begin{array}{c}19.95 \pm 0.56 \\
(0 \%)\end{array}$ & $\begin{array}{c}19.98 \pm 0.78 \\
(0 \%)\end{array}$ \\
\hline 2 & $\begin{array}{c}18.06 \pm 0.77 \\
(9.7 \%)\end{array}$ & $\begin{array}{c}18.02 \pm 0.52 \\
(9.9 \%)\end{array}$ & $\begin{array}{c}17.52 \pm 0.63 \\
(12.4 \%)\end{array}$ & $\begin{array}{c}17.12 \pm 0.84 \\
(19.4 \%)\end{array}$ & $\begin{array}{c}16.65 \pm 0.92 \\
(16.75 \%)\end{array}$ & $\begin{array}{c}16.12 \pm 0.06 \\
(19.4 \%)\end{array}$ \\
\hline 4 & $\begin{array}{c}16.09 \pm 0.32 \\
(19.6 \%)\end{array}$ & $\begin{array}{c}15.69 \pm 0.53 \\
(21.55 \%)\end{array}$ & $\begin{array}{c}15.5 \pm 0.29 \\
(22.2 \%)\end{array}$ & $\begin{array}{c}18.24 \pm 0.25 \\
(24.4 \%)\end{array}$ & $\begin{array}{c}13.95 \pm 0.69 \\
(30.25 \%)\end{array}$ & $\begin{array}{c}13.25 \pm 0.55 \\
(33.75 \%)\end{array}$ \\
\hline 6 & $\begin{array}{c}15.03 \pm 0.88 \\
(24.55 \%)\end{array}$ & $\begin{array}{c}13.46 \pm 1.20 \\
(32.7 \%)\end{array}$ & $\begin{array}{c}12.98 \pm 0.95 \\
(35.1 \%)\end{array}$ & $\begin{array}{c}12.22 \pm 1.29 \\
(39 \%)\end{array}$ & $\begin{array}{c}6.8 \pm 0.25 \\
(67.5 \%)\end{array}$ & $\begin{array}{c}6.12 \pm 0.99 \\
(69.4 \%)\end{array}$ \\
\hline 8 & $\begin{array}{c}14.07 \pm 1.04 \\
(29.65 \%)\end{array}$ & $\begin{array}{c}12.5 \pm 0.5 \\
(37.5 \%)\end{array}$ & $\begin{array}{c}6.98 \pm 0.46 \\
(65.1 \%)\end{array}$ & $\begin{array}{c}6.25 \pm 0.25 \\
(68.25 \%)\end{array}$ & $\begin{array}{c}3.25 \pm 0.32 \\
(83.75 \%)\end{array}$ & $\begin{array}{c}3.06 \pm 0.84 \\
(84.7 \%)\end{array}$ \\
\hline 10 & $\begin{array}{c}13.04 \pm 0.62 \\
(34.85 \%)\end{array}$ & $\begin{array}{c}9.35 \pm 0.94 \\
(53.25 \%)\end{array}$ & $\begin{array}{c}3.21 \pm 1.25 \\
(83.95 \%)\end{array}$ & $\begin{array}{c}3.12 \pm 0.15 \\
(84.14 \%)\end{array}$ & $\begin{array}{c}1.75 \pm 0.57 \\
(91.25 \%)\end{array}$ & $\begin{array}{c}1.53 \pm 0.28 \\
(92.35 \%)\end{array}$ \\
\hline 12 & $\begin{array}{c}10.09 \pm 0.40 \\
(49.55 \%)\end{array}$ & $\begin{array}{c}4.04 \pm 0.38 \\
(79.55 \%)\end{array}$ & $\begin{array}{l}1.5 \pm 0.05 \\
(92.5 \%)\end{array}$ & $\begin{array}{c}1.4 \pm 0.84 \\
(93 \%)\end{array}$ & $\begin{array}{c}0.87 \pm 0.46 \\
(95.65 \%)\end{array}$ & $\begin{array}{c}0.76 \pm 0.24 \\
(96.5 \%)\end{array}$ \\
\hline
\end{tabular}

(Values are mean \pm SD of three animals in each group. Numbe rs in parenthesis indicates the \% wound contraction)

Table 4: Wound healing data of mupirocin loaded chitosan-alginate composite films formulated with and without glutaraldehyde along with aloe vera

\begin{tabular}{|c|c|c|c|c|c|c|}
\hline \multirow{2}{*}{$\begin{array}{c}\text { Post- } \\
\text { wounding } \\
\text { days }\end{array}$} & \multicolumn{6}{|c|}{ Wound area $(\mathrm{mm})$} \\
\hline & Control & Standard & F9 & F10 & F11 & F12 \\
\hline 0 & $\begin{array}{c}20.03 \pm 0.81 \\
(0 \%)\end{array}$ & $\begin{array}{c}20.35 \pm 0.76 \\
(0 \%)\end{array}$ & $\begin{array}{c}20.02 \pm 0.79 \\
(0 \%)\end{array}$ & $\begin{array}{c}19.98 \pm 0.32 \\
(0 \%)\end{array}$ & $\begin{array}{c}19.98 \pm 0.65 \\
(0 \%)\end{array}$ & $\begin{array}{c}19.25 \pm 0.65 \\
(0 \%)\end{array}$ \\
\hline 2 & $\begin{array}{c}18.06 \pm 0.77 \\
(9.7 \%)\end{array}$ & $\begin{array}{c}18.02 \pm 0.52 \\
(9.9 \%)\end{array}$ & $\begin{array}{c}17.14 \pm 0.93 \\
(14.13 \%)\end{array}$ & $\begin{array}{c}17.01 \pm 0.49 \\
(14.95 \%)\end{array}$ & $\begin{array}{c}15.92 \pm 0.77 \\
(20.4 \%)\end{array}$ & $\begin{array}{c}15.95 \pm 0.24 \\
(20.25 \%)\end{array}$ \\
\hline 4 & $\begin{array}{c}16.09 \pm 0.32 \\
(19.6 \%)\end{array}$ & $\begin{array}{c}15.69 \pm 0.53 \\
(21.55 \%)\end{array}$ & $\begin{array}{c}14.92 \pm 1.26 \\
(25.4 \%)\end{array}$ & $\begin{array}{c}14.91 \pm 0.86 \\
(25.45 \%)\end{array}$ & $\begin{array}{c}13.13 \pm 1.11 \\
(34.35 \%)\end{array}$ & $\begin{array}{c}12.92 \pm 0.14 \\
(35.25 \%)\end{array}$ \\
\hline 6 & $\begin{array}{c}15.03 \pm 0.88 \\
(24.55 \%)\end{array}$ & $\begin{array}{c}13.46 \pm 1.20 \\
(32.7 \%)\end{array}$ & $\begin{array}{c}12.25 \pm 0.22 \\
(38.75 \%)\end{array}$ & $\begin{array}{c}12.01 \pm 0.69 \\
(39.45 \%)\end{array}$ & $\begin{array}{c}6.14 \pm 0.28 \\
(69.3 \%)\end{array}$ & $\begin{array}{c}6 \pm 0.29 \\
(70 \%)\end{array}$ \\
\hline 8 & $\begin{array}{c}14.07 \pm 1.04 \\
(29.65 \%)\end{array}$ & $\begin{array}{c}12.5 \pm 0.5 \\
(37.5 \%)\end{array}$ & $\begin{array}{c}6.25 \pm 0.38 \\
(68.75 \%)\end{array}$ & $\begin{array}{c}5.84 \pm 0.26 \\
(70.75 \%)\end{array}$ & $\begin{array}{c}2.92 \pm 0.29 \\
(85.4 \%)\end{array}$ & $\begin{array}{c}2.98 \pm 0.94 \\
(85 \%)\end{array}$ \\
\hline 10 & $\begin{array}{c}13.04 \pm 0.62 \\
(34.85 \%)\end{array}$ & $\begin{array}{c}9.35 \pm 0.94 \\
(53.25 \%)\end{array}$ & $\begin{array}{c}3.14 \pm 1.43 \\
(84.3 \%)\end{array}$ & $\begin{array}{c}2.95 \pm 0.82 \\
(89.25 \%)\end{array}$ & $\begin{array}{c}1.4 \pm 0.22 \\
(93 \%)\end{array}$ & $\begin{array}{c}1.32 \pm 0.46 \\
(93.4 \%)\end{array}$ \\
\hline 12 & $\begin{array}{c}10.09 \pm 0.40 \\
(49.55 \%)\end{array}$ & $\begin{array}{c}4.04 \pm 0.38 \\
(79.55 \%)\end{array}$ & \begin{tabular}{|cc}
1.1 & \pm 0.21 \\
& $(94.5 \%)$
\end{tabular} & $\begin{array}{c}1.25 \pm 0.28 \\
(93.75 \%)\end{array}$ & $\begin{array}{c}0.22 \pm 0.06 \\
(98.9 \%)\end{array}$ & $\begin{array}{c}0.12 \pm 0.04 \\
(99.4 \%)\end{array}$ \\
\hline
\end{tabular}

(Values are mean \pm SD of three animals in each group. Numbe rs in parenthesis indicates the \% wound contraction) 


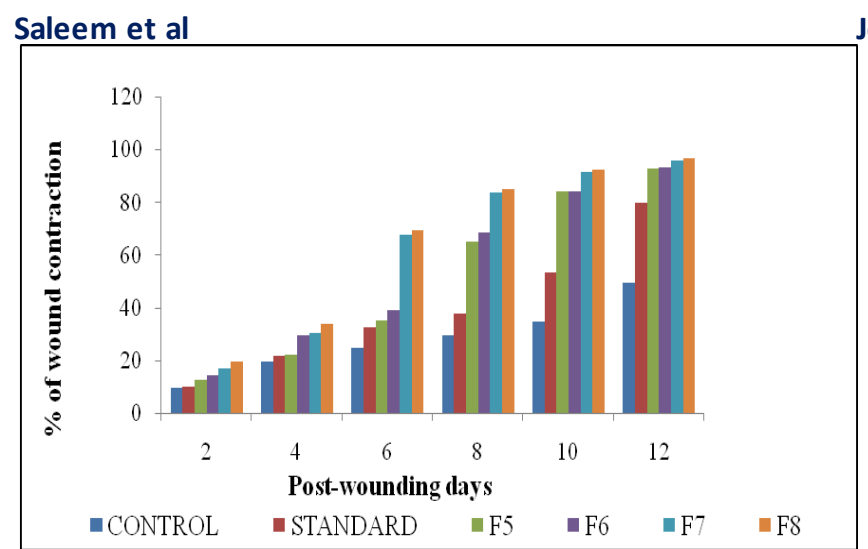

Figure 4: Comparative \%wound healing of control and standard with polymer composite films formulated with and without glutaraldehy de containing aloe vera

All the plane chitosan composite films without glutaraldehyde showed increase in \% wound contraction as compared to control and standard at $12^{\text {th }}$ day. Control showed $49.55 \%$, standard $79.55 \%$ where as F5 showed $92.5 \%$ and F7 $95.65 \%$. The chitosan-alginate composite films prepared with glutaraldehyde showed percentage of wound contraction as F6 93\% and F8 96.5\%. The results of addition of glutaraldehyde in the chitosan-alginate did not show much deviation as compared to films without glutaraldehyde. Aloe vera is ancient herbal medicine used as

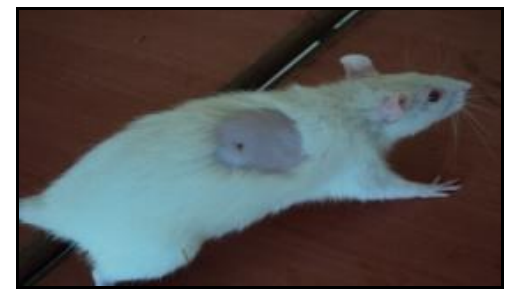

Journal of Drug Delivery \& Therapeutics; 2012, 2(3): 167-172

a wound healing accelerator because of its anti-microbial effect, anti-fungal activity and epitheliazation of damaged tissue cells. Mupirocin is a broad spectrum topical antibiotic. Mupirocin loaded chitosan-alginate composite films showed \% maximum wound contraction of $94.5 \%$ for F9, $93.75 \%$ for $\mathrm{F} 10,98.9 \%$ for $\mathrm{F} 11$ and $99.4 \%$ for $\mathrm{F} 12$. These results suggested that addition of mupirocin further accelerate the healing by prevention of secondary wound infections and the wound was completely healed with in 12 days as shown in figure 6.

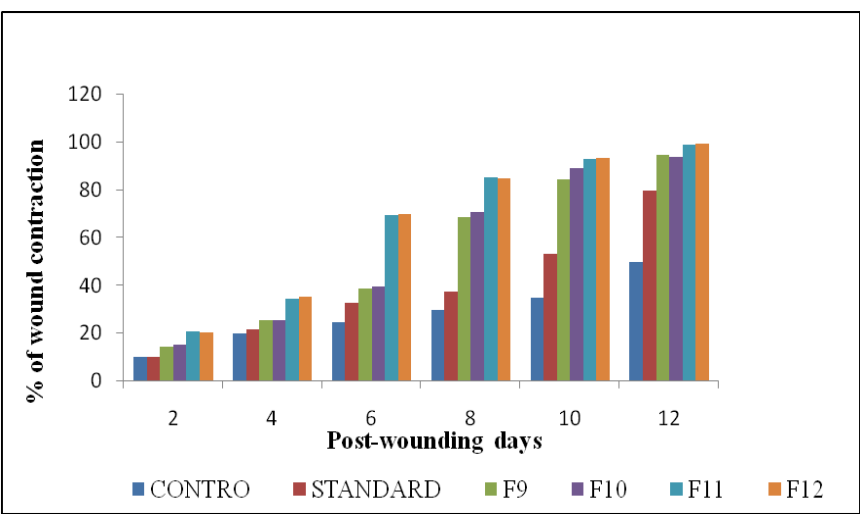

Figure 5: Comparative \%wound healing of control and standard with mupirocin incorporated poly mer composite films formulated with and without glutaraldehyde containing aloe vera

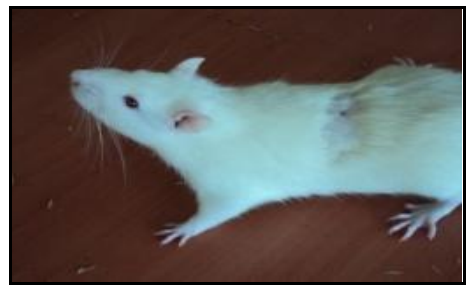

Figure 6: Completely healed wound after $12^{\text {th }}$ day for mupirocin loaded poly mer composite films F11 \& F12

\section{CONCLUS ION}

The chitosan polymer composite films containing glutaraldehyde as crosslinker have uniform thickness with good flexibility, good tensile strength, absorb more mo isture with excellent bioadhesion and good swelling. All the polymeric films showed more than $80 \%$ reduction in wound contraction. The mupirocin loaded polymeric composite containing aloe vera, showed more than $98 \%$ of reduction in wound area after $12^{\text {th }}$ day. Hence it can be concluded that mupirocin incorporated chitosan-alginate films along with aloe vera containing glutaraldehyde may be excellent new dressing for wound occlusion/tissue repairing and could be REFERENCES

1. www.woundheal.org/.../final\%20pocket $\% 0$ guide $\% 20$ treat ment.pdf

2. Queen D, Orsted H, Sanada H, Sussman G, A Dressing history, Int Wound J, 2004, 1, 59-77.

3. Turner TD, Products and their development in wound management, Plastic Surgery Journal, 1979, 75-84.

4. Boateng JS, Matthews KH, Stevens HN, Eccleston GM, Wound healing dressings and drug delivery systems: A review, J. Pharm Sci, 2008, 97(8), 2892-2923.

5. Wittaya-areekul S, Chreerat P, Development and in vitro evaluation of chitosan-polysaccharide composite wound dressing, Int. J Pharm, 2006, 313, 123-128.

6. Thomas S, Alginate dressing in surgery and wound management: Part 1, J Wound Care, 2000, 9, 56-60.

7. Prajapati G, Sawant K, Polyelectrolyte complex of chitosan-alginate for local drug delivery, Int J Chem T ech Reseach, 2009, 1(3), 643-648.

8. Hamman $\mathrm{JH}$, Composition and application of Aloevera leaf gel, 15 Molecules, 2008, 13, 1599-1616. used for effective treatment of all types of wound. Hence mupirocin incorporated chitosan-alginate films along with aloe vera containing glutaraldehyde may be promising new dressing for wound occlusion/tissue repairing and could be used for effective treatment of all types of wound.

ACKNOWLEDGEMENT: The authors are thankful to India Sea Foods, Cochin for gift sample of chitosan, Glenmark Pharmaceuticals Ltd, Nasik for gift sample of mupirocin and Biomax Life Sciences, Hyderabad for aloe vera sample.

DECLARATION OF INTEREST: Authors show no conflict of interest

9. Georgina G, Role of topical antimicrobial in wound management, J Wound Care/ACTIVA Health Care Supplement, 2009, 4-8.

10. http://www.drugbank.ca/Drugs/DB00410.

11. Wittaya-areekul S, Chureerat $\mathrm{P}$, Sungthongjeen S, Development and invitro evaluation of chitosan-eudragit RS 30D composite wound dressing, AAPS Pharm Sci Tech, 2006, 7(1), E1-E6.

12. Sezer AD et al, Chitosan film containing fucoidan as a wound dressing for dermal burn healing: preparation and invitro/invivo evaluation, AAPS Pharm Sci Tech, 2007, 8(2): E1-E6.

13. Khan TA, Peh KK and Ch'ng HS, Mechanical, bioadhesive strength and biological evaluation of chitosan films for wound dressing, $\mathbf{J}$ Pharm Sci.2000, 3(3). 303-311.

14. Vidyavathi M, Himabindu TVL, Kavitha K, Sastry TP, SureshKumar RV, Preparation and evaluation of ciprofloxacin loaded chitosan-gelat in composite films for wound healing activity, IJDD, 2010, 2, 173-182.

15. Sabeena M, Emmanuel S, Revathi K, Ignacimuthu S, Wound healing activity of Cassiaoccidentalis $L$ in wister albino rats, Int $\mathrm{J}$ of Inegrative Biology, 2009, 8(1), 1-6. 
